\title{
Eurasian Arctic climate over the past millennium as recorded in the Akademii Nauk ice core (Severnaya Zemlya)
}

\author{
T. Opel, D. Fritzsche, and H. Meyer \\ Alfred Wegener Institute Helmholtz Centre for Polar and Marine Research, Research Unit Potsdam, Telegrafenberg A43, \\ 14473 Potsdam, Germany
}

Correspondence to: T. Opel (thomas.opel@awi.de)

Received: 10 April 2013 - Published in Clim. Past Discuss.: 8 May 2013

Revised: 4 September 2013 - Accepted: 20 September 2013 - Published: 23 October 2013

\begin{abstract}
Understanding recent Arctic climate change requires detailed information on past changes, in particular on a regional scale. The extension of the depth-age relation of the Akademii Nauk (AN) ice core from Severnaya Zemlya (SZ) to the last $1100 \mathrm{yr}$ provides new perspectives on past climate fluctuations in the Barents and Kara seas region. Here, we present the easternmost high-resolution ice-core climate proxy records $\left(\delta^{18} \mathrm{O}\right.$ and sodium) from the Arctic. Multiannual $\mathrm{AN} \delta^{18} \mathrm{O}$ data as near-surface air-temperature proxies reveal major temperature changes over the last millennium, including the absolute minimum around 1800 and the unprecedented warming to a double-peak maximum in the early 20th century. The long-term cooling trend in $\delta^{18} \mathrm{O}$ is related to a decline in summer insolation but also to the growth of the AN ice cap as indicated by decreasing sodium concentrations. Neither a pronounced Medieval Climate Anomaly nor a Little Ice Age are detectable in the $\mathrm{AN} \delta^{18} \mathrm{O}$ record. In contrast, there is evidence of several abrupt warming and cooling events, such as in the 15th and 16th centuries, partly accompanied by corresponding changes in sodium concentrations. These abrupt changes are assumed to be related to sea-ice cover variability in the Barents and Kara seas region, which might be caused by shifts in atmospheric circulation patterns. Our results indicate a significant impact of internal climate variability on Arctic climate change in the last millennium.
\end{abstract}

\section{Introduction}

The climate of the Arctic is characterized by ongoing drastic changes. The rapid Arctic warming is accompanied by an unprecedented sea-ice retreat and other positive climate feedback processes, such as permafrost warming and thawing as well as melting of glaciers and ice caps. Projections of future climate change indicate a continuation and amplification of these processes in the next decades (e.g. AMAP, 2011).

Knowledge of the natural climate variability is essential to understand and assess the ongoing climate change and for reliable predictions of future climate development. Meteorological records of the Arctic are sparse and relatively short, with only very few time series starting before the 20th century (e.g. Polyakov et al., 2003b). The longest continuous time series of surface air temperature (SAT) in the Eurasian Arctic (Vard $\varnothing$, Northern Norway) dates back to 1840. In the Russian subarctic the SAT time series of Arkhangelsk started in 1814 (with an interruption of two years in 1832/1833).

Hence, high-resolution climate archives such as ice cores are needed to provide substantial information on the temporal and spatial patterns of the natural Arctic climate variability and its causes (e.g. Overpeck et al., 1997) as well as for an assessment of the recent Arctic warming from a centennialto millennial-scale perspective. Of particular interest are climate changes in the Mid- to Late Holocene, characterized by relatively stable boundary conditions of the climate system and by a negligible anthropogenic influence in the preindustrial period before about 1750 (Wanner et al., 2008).

Several palaeoclimate records indicate that the recent Arctic warming and its implications (such as a sea-ice cover reduction) are unprecedented in the Late Holocene, i.e. the 
last 2000 yr (e.g. Kaufman et al., 2009; Kinnard et al., 2011; Spielhagen et al., 2011; PAGES 2k Consortium, 2013). However, for a more comprehensive assessment of the natural Late Holocene climate changes in the Arctic, their causes and feedbacks, more regional palaeoclimate information is required. This is particularly true for the Eurasian Arctic (here regarded as between $0^{\circ}$ longitude and the Bering Strait) as compared to the North American Arctic. Only five out of 29 records used for the Arctic temperature reconstructions of Overpeck et al. (1997), six out of 23 of Kaufman et al. (2009) and 21 out of 59 of the PAGES 2k Consortium (2013) are from the Eurasian Arctic. These records are mostly from tree rings and lake sediments and the majority is from Scandinavia (twice as much as from the much larger Russian Arctic for the two latter reconstructions).

Ice-core records of the Eurasian Arctic are limited to High Arctic archipelagos such as Svalbard, Franz Josef Land (FJL) and Severnaya Zemlya (SZ) (Fig. 1). Glaciers and ice caps in the Eurasian Arctic are characterized by summertime surface melting and hence require special consideration of meltwater percolation processes (Koerner, 1997). Nevertheless, they may contain high-resolution palaeoclimate information on a regional scale. Consequently, several ice cores were drilled in the last two decades at Svalbard and FJL (Fig. 1), providing climate records reaching several hundred years back in time (e.g. Henderson, 2002; Isaksson et al., 2005; Divine et al., 2011).

To extend high-resolution ice-core-based palaeoclimate information eastwards, a joint German-Russian team drilled a $724 \mathrm{~m}$ long ice core to bedrock close to the summit of the Akademii Nauk (AN) ice cap at SZ in the Central Russian Arctic $\left(80.52^{\circ} \mathrm{N}, 94.82^{\circ} \mathrm{E}\right.$, about $750 \mathrm{~m}$ a.s.l., Fig. 1) from 1999 to 2001 (Fritzsche et al., 2002). The AN ice cap might be the oldest one in the Eurasian Arctic (Koerner and Fisher, 2002), even though maximum ages of 10 to 40 thousand years reported for an ice core drilled in 1986/1987 on the AN ice cap are distinctly overestimated (Kotlyakov et al., 2004; Fritzsche et al., 2005).

An automatic weather station near the drilling site yielded a mean annual air temperature of $-15.7^{\circ} \mathrm{C}$ (May 1999 to April 2000). During the summer months, temperatures may rise above $0^{\circ} \mathrm{C}$ and cause snowmelt and percolation of meltwater into the surface layers. For more detailed information on climate conditions as well as drilling-site characteristics including snowmelt and infiltration, we refer to Opel et al. (2009). A mean modern accumulation rate of about $0.46 \mathrm{~m}$ water equivalent (w.e.) per year for the period 1956-1999 was found by Fritzsche et al. (2005) based on high-resolution stable water isotope analysis.

Hitherto existing results of AN ice-core analysis indicate that despite meltwater infiltration the AN ice core may be a key archive for the reconstruction of the Late Holocene climate and environmental history of the Eurasian Arctic (Fritzsche et al., 2005; Weiler et al., 2005; Opel et al., 2009).

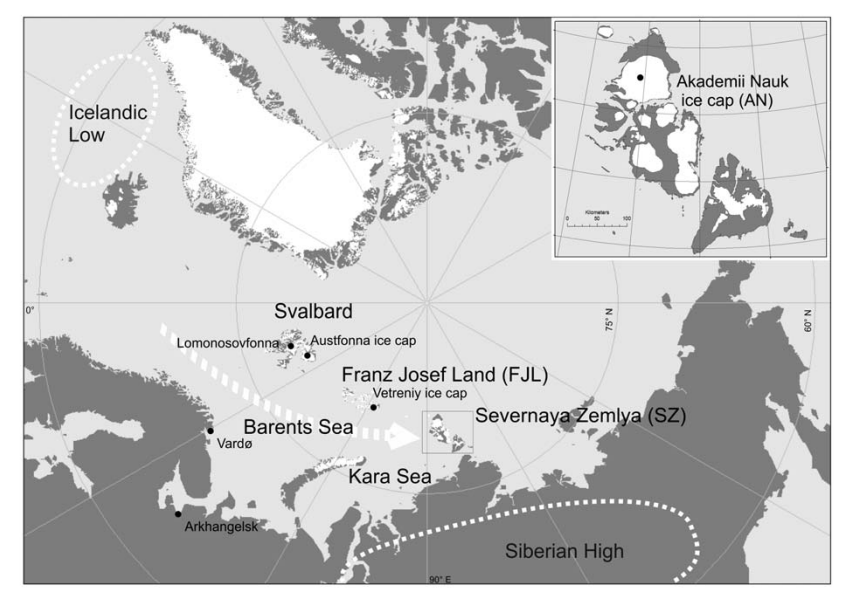

Fig. 1. Map of the Eurasian Arctic (Inset: Severnaya Zemlya with the drilling point at Akademii Nauk ice cap) including schematic positions of Icelandic Low and Siberian High as well as the major air-mass transport pathway (dashed arrow) for SZ. Locations mentioned in the text are labelled.

In this paper, we present stable water isotope and majorion records from the core section with a well established depth-age relationship, i.e. the upper $411 \mathrm{~m}$ of the AN ice core, covering the last $1100 \mathrm{yr}$. These are the first highresolution ice-core time series from the central Eurasian Arctic exceeding the past millennium. The data add valuable new information on the temporal and spatial patterns of climate variations in the poorly studied Eurasian Arctic. We show that this region experienced major climate variability over the past millennium and discuss long-term trends and abrupt changes as well as possible causes in the Arctic context.

\section{Methods and data}

\subsection{Ice-core data}

Ice-core processing and sampling took place in the cold laboratory of the Alfred Wegener Institute Helmholtz Centre for Polar and Marine Research (AWI) Bremerhaven (for details and additional references, see Fritzsche et al., 2005; Opel et al., 2009). After the determination of electrical conductivity and density by dielectric profiling and $\gamma$-absorption techniques (Wilhelms, 2000), two core-axis-parallel slices (12 and $32 \mathrm{~mm}$ thick) were cut.

The first one was sampled in a high sub-annual resolution of $2.5 \mathrm{~cm}$ for stable water isotope measurements. The oxygen $\left(\delta^{18} \mathrm{O}\right)$ and hydrogen $(\delta \mathrm{D})$ stable-isotope compositions were analysed at the AWI Potsdam using a Finnigan MAT Delta-S mass spectrometer with an analytical precision of better than $\pm 0.1 \%$ ofor $\delta^{18} \mathrm{O}$ and $\pm 0.8 \%$ o for $\delta \mathrm{D}$ (Meyer et al., 2000). In total, about 16200 samples were analysed for this paper.

After scanning with a line-scan camera the second slice was sampled for glaciochemistry. Screening samples (from 
single core segments, i.e. 0.3 to $1.0 \mathrm{~m}$ ) were taken by a melting device for continuous flow analysis coupled with an autosampler system. High-resolution sampling (about $5 \mathrm{~cm}$ ) for selected core sections was done by the same system or by cutting under clean conditions. The major-ion concentrations were determined using a Dionex IC20 ion chromatograph at the glaciochemistry laboratory of the AWI Bremerhaven (for details, see Weiler et al., 2005).

\subsection{Meteorological data}

For comparing our AN ice-core proxy data to meteorological data we selected SAT time series from the CRU Norwich's HadCRUT3 dataset (Brohan et al., 2006). Additionally we used two SAT compilations for the Arctic (Polyakov et al., 2003b) and the Atlantic-Arctic boundary region (Wood et al., 2010), respectively. All these time series are based on meteorological station data.

\section{Ice-core dating}

The dating of the upper section (0-411 m) of AN ice core is based on reference horizons and annual-layer counting. As reference horizons we used the $1963{ }^{137}$ Cs peak caused by the fallout from nuclear bomb tests (Fritzsche et al., 2002; Pinglot et al., 2003) as well as volcanic signals. We clearly identified outstanding peaks in non-sea-salt (nss) sulfate concentrations and linked them to the major volcanic eruptions of Bezymianny (Kamchatka) in 1956, Katmai/Novarupta (Alaska) in 1912, Laki (Iceland) in 1783 and the unknown volcano in 1259 (Fig. 2), also detected in ice cores from Greenland (Zielinski et al., 1994), Svalbard (e.g. Moore et al., 2012) and FJL (Henderson, 2002). Additionally, we interpreted a smaller peak as the imprint of the Eldgja (Iceland) eruption in 934, also found in Greenland ice cores (Zielinski et al., 1994). So far we have not identified more distinct nss sulfate signals that can be related to certain volcanic eruptions. As about $50 \%$ of the sulfate in the AN ice core originates from sea salt before the anthropogenically influenced 20th century (Weiler et al., 2005), volcanic sulfate peaks might be masked in the screening data.

For an independent annual-layer counting, we used seasonal signals of high-resolution stable water isotope data, which are clearly detectable in most cases, even though they might be smoothed and altered by meltwater infiltration. We differentiate single years using $\delta^{18} \mathrm{O}$ and $\delta \mathrm{D}$ winter minima and respective winter maxima in deuterium excess $d$ $\left(d=\delta \mathrm{D}-8 \delta^{18} \mathrm{O}\right)$, since $\delta$ values and $d$ excess do not show significant phase lags (Fig. 3).

The annual-layer-based chronology was then crosschecked with the reference horizons. Both approaches were combined and matched, resulting in our AN icecore chronology (AN 2012). It comprises about $1100 \mathrm{yr}$ for the core section presented here $(0-411 \mathrm{~m}$, corresponding to

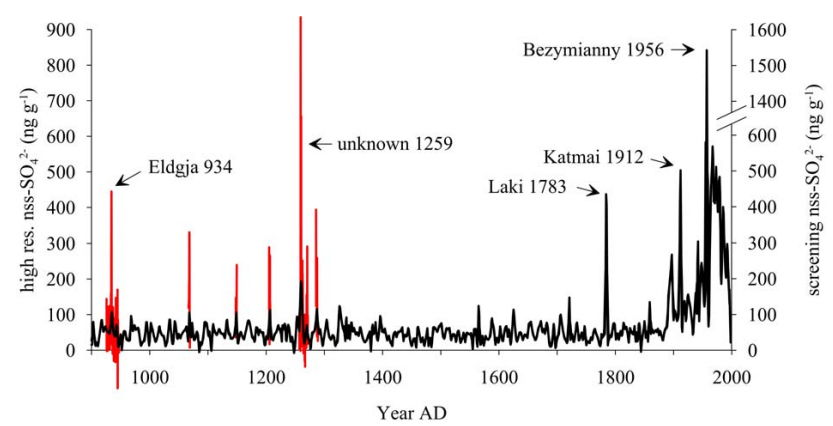

Fig. 2. $\mathrm{AN}$ nss $\mathrm{SO}_{4}^{2-}$ record with annual values based on screening data in black (right axis); high-resolution data for selected core sections in red (left axis). Peaks interpreted as volcanic reference horizons are labelled.

0-373 m w.e.), i.e. the time period 900-1998. Based on the cross-checking of both dating approaches and the comparison with an adjusted Nye model (see below) we estimate a dating uncertainty better than $\pm 3 \mathrm{yr}$ after 1783 and better than $\pm 10 \mathrm{yr}$ throughout the time period 934 to 1783 .

The resulting age (about $1100 \mathrm{yr}$ ) is distinctly younger than calculated with a standard Nye (1963) model (about $1250 \mathrm{yr}$, Fig. 4) for the same depth of $411 \mathrm{~m}$ or claimed by Kotlyakov et al. (1990) for the corresponding section of the AN ice core taken in 1986/1987 (about 2700 yr). Both age models underestimate the annual-layer thickness and, therefore, overestimate the age (Fig. 4). Consequently, the AN ice cap is much younger than previously assumed. It is not in dynamic steady state and most probably has been growing until recent times. This assumption has been tested by an adjusted Nye model that takes into account the growing ice cap by adding a growth term (Fritzsche et al., 2010).

Our preliminary chronology for the whole AN ice core based on this approach exhibits an age of about $3100 \mathrm{yr}$ at a possible discordance at a depth of about $694 \mathrm{~m}, 30 \mathrm{~m}$ above bedrock. The lowermost core section (694-724 m) contains ice that might be a remnant of an older ice-cap stage. However, this ice is clearly of post-glacial age as indicated by a mean $\delta^{18} \mathrm{O}$ value of $-20.1 \%$ o (range: -23.7 to $-16.8 \%$ ).

We calculated annual mean values by averaging all data between the defined annual marks (high-resolution stable water isotope data) as well as by resampling of screening data (major ions) using a polynomial fit function based on our core chronology. To minimize the effects of meltwater infiltration as well as dating uncertainties we only use running mean values over five and $15 \mathrm{yr}$ ( $5 \mathrm{yrm}$ and $15 \mathrm{yrm}$, respectively) for climatic interpretation. 

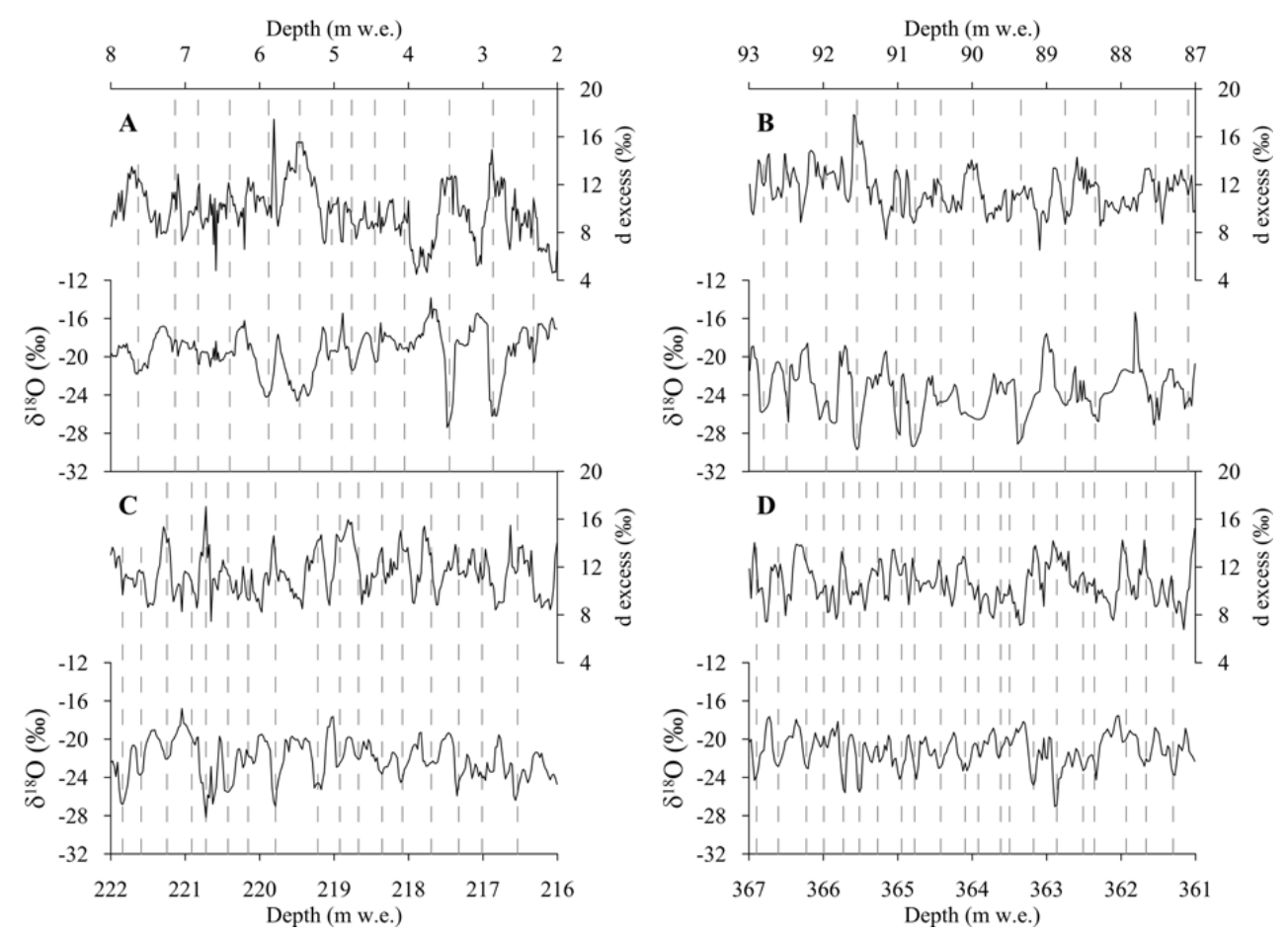

Fig. 3. High-resolution $\delta^{18} \mathrm{O}$ and $d$ excess values (raw data) for different sections of AN ice core: (A) 2-8 $\mathrm{m} \mathrm{w.e.} \mathrm{(3.35-12.05} \mathrm{m),} \mathrm{(B)} \mathrm{87-}$ 93 m w.e. (100.22-106.75 m), (C) 216-222 m w.e. (240.30-246.92 m), and (D) 361-367 m w.e. (397.97-404.49 m). The decreasing annuallayer thickness with increasing depth is clearly detectable. Interpreted annual marks, i.e. winter signals, are marked by dashed grey lines. The core sections correspond to the following time periods (only complete annual cycles are considered, from left to right): (A) 1982-1993, (B) 1780-1791, (C) 1419-1434, (D) 927-946.

\section{Results and discussion}

\subsection{Comparison of $\mathrm{AN} \delta^{18} \mathrm{O}$ to meteorological data (1800-1998)}

We compared our AN $\delta^{18} \mathrm{O}$ dataset to the two longest meteorological time series of the Eurasian Arctic and subarctic, i.e. Vard $\varnothing$ and Arkhangelsk, as well as to two SAT compilations based on meteorological station data (Fig. 5). Before the calculation of correlation coefficients, we detrended the time series for the respective common time periods by subtracting the linear trends. As those mainly represent the general warming in the time period of overlap, the resulting correlation coefficients are distinctly lower than for the original time series (Table 1).

For station time series a striking similarity and the highest correlation to our $\mathrm{AN} \delta^{18} \mathrm{O}$ record was found for Vardø in Northern Norway (1840-1998, Figs. 1 and 5). Annual mean SAT values ( $5 \mathrm{yrm}$ ) are strongly correlated with $r_{5 \mathrm{yrm}}=0.55$ (Table 1). The correlation to the Arkhangelsk (northeastern Russia, Fig. 1) annual mean SAT record (1814-1998) is only slightly lower $\left(r_{5 \mathrm{yrm}}=0.51\right.$, Table 1 , Fig. 5$)$. The best accordance of annual AN $\delta^{18} \mathrm{O}$ values with the Vard $\varnothing$ SAT time series is also valid on a seasonal scale, with the highest correlation coefficients for autumn $\left(\mathrm{SON}, r_{5 \mathrm{yrm}}=0.51\right)$, winter
(DJF, $\left.r_{5 \mathrm{yrm}}=0.46\right)$ and summer $\left(\mathrm{JJA}, r_{5 \mathrm{yrm}}=0.43\right)$ seasons (Table 1). This corresponds well with the generally yearround distribution of precipitation on the AN ice cap (Opel et al., 2009) and supports the interpretation of $\mathrm{AN} \delta^{18} \mathrm{O}$ data as proxies for annual SAT.

The correlations of $\mathrm{AN} \delta^{18} \mathrm{O}$ to Vard $\varnothing$ and Arkhangelsk SAT presented here are slightly weaker than those for 1883 1998 (Opel et al., 2009). This indicates somewhat greater differences in the mid-19th century and/or different characteristics of the subtracted linear trends due to other reference periods.

Comparable correlations were not only found for the individual meteorological time series mentioned above and that already presented by Opel et al. (2009) for the period 1883-1998 but also for SAT compilations (Table 1, Fig. 5). Whereas $\mathrm{AN} \delta^{18} \mathrm{O}$ data correlate with $r_{5 \mathrm{yrm}}=0.47$ to the SAT of the North Atlantic-Arctic boundary region ( $T_{\mathrm{NA}}$, 1802-1998) of Wood et al. (2010), the correlation to the Arctic-wide SAT compilation (1875-1998) of Polyakov et al. $(2003 \mathrm{~b})$ is considerably higher $\left(r_{5 \mathrm{yrm}}=0.72\right)$, underlining the spatial significance of our $\mathrm{AN} \delta^{18} \mathrm{O}$ record.

In summary, $\mathrm{AN} \delta^{18} \mathrm{O}$ data can be considered as reliable proxies for annual SAT in the western Eurasian Arctic despite meltwater infiltration. The significance of the AN $\delta^{18} \mathrm{O}$ record might be even undervalued, considering the long 

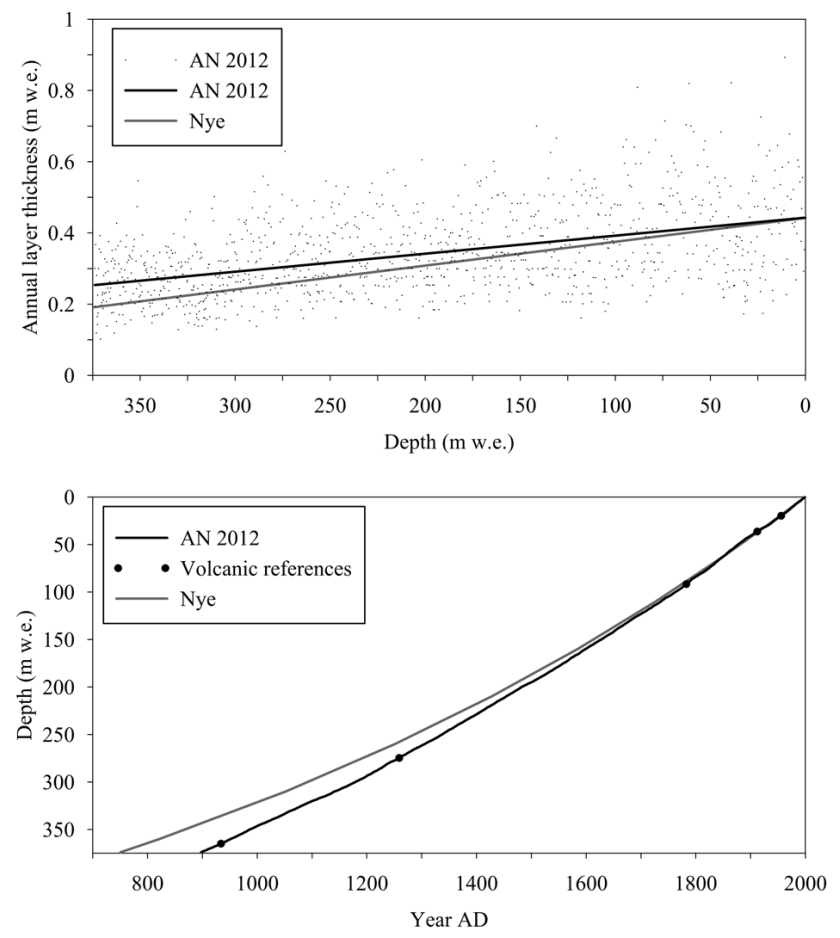

Fig. 4. (Top) Annual-layer thickness of AN ice core (dots) derived from stable-isotope-based layer counting, linear fit of annuallayer thickness (black line) and annual-layer thickness derived from a Nye model (grey line). (Bottom) Depth-age relations of core chronology AN 2012 (black line) and based on a Nye model calculated with an accumulation rate of $0.44 \mathrm{~m}$ w.e. and an ice-cap thickness of $660 \mathrm{~m}$ w.e. (grey line) for the studied core section. Black dots represent volcanic reference horizons.

distances from the AN ice cap to meteorological stations, the different elevations and climate regimes as well as dating uncertainties, which all ought to decrease the correlations.

From the high accordance of AN $\delta^{18} \mathrm{O}$ data with SAT time series from more maritime North Atlantic-influenced sites (i.e. Northern Norway, Svalbard) the conclusion can be drawn that the SAT regime of the Barents and Kara seas region is strongly influenced by the North Atlantic due to its dominant role for the atmospheric and ocean circulations in this region. However, the more continental climate of SZ is indicated by the larger SAT range observed in the standardized $\mathrm{AN} \delta^{18} \mathrm{O}$ record over the past two centuries in comparison to the Vard $\varnothing$ and Arkhangelsk SAT time series (Fig. 5).

Our AN $\delta^{18} \mathrm{O}$ data reveal a general warming trend over the 19th and 20th centuries (about 2\%o per century; Fig. 5). Superimposed on this trend was the early-twentieth century warming (ETCW), a major Arctic-wide climatic fluctuation between 1920 and 1940 (Wood and Overland, 2010). This event is commonly related to internal dynamics of the Arctic climate system, i.e. a stronger than normal meridional circulation and corresponding heat transport into the European Arctic, connected to a strengthened Icelandic Low and a

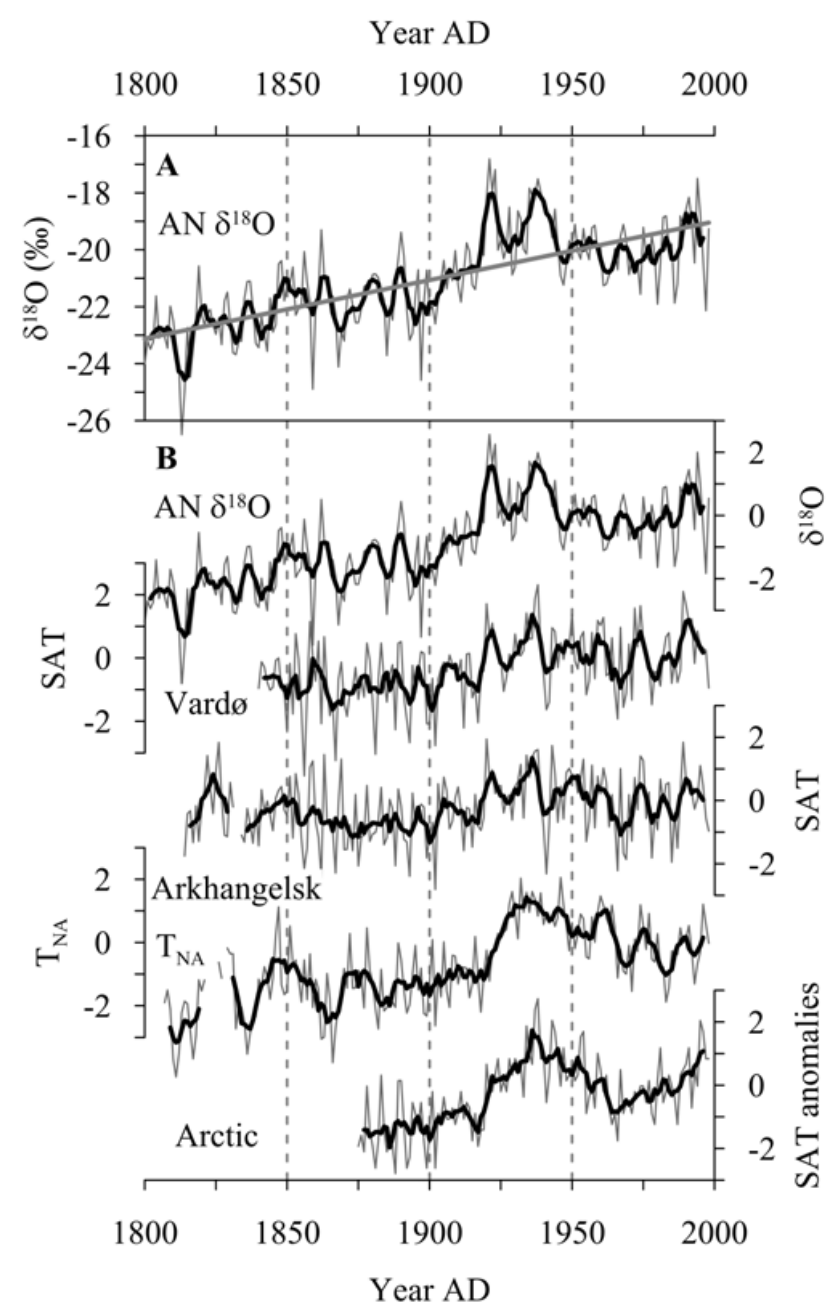

Fig. 5. AN $\delta^{18} \mathrm{O}$ record compared to meteorological data and compilations. (A) Original $\mathrm{AN} \delta^{18} \mathrm{O}$ record (including linear trend in grey). (B) (From top to bottom) Standardized time series of AN $\delta^{18} \mathrm{O}$, Vard $\varnothing$ and Arkhangelsk SATs (Brohan et al., 2006), AtlanticArctic boundary region SAT anomalies ( $T_{\mathrm{NA}}$ ) (Wood et al., 2010) and Arctic SAT anomalies (Polyakov et al., 2003b). For better comparison the time series are plotted as normalized deviations $(z)$ from the 1900-1998 mean $(m): z=(x-m) / s$, where $s$ is the standard deviation of the raw series for the period 1900-1998. Displayed are annual values (grey lines) and 5 yrm values (thick black lines).

westward expansion of the Siberian High (Grant et al., 2009; Wood and Overland, 2010). The resulting warming induced a reduction of sea-ice cover and albedo mostly in the Barents Sea region. This was accompanied by a reinforced regional cyclonic circulation and, thus, a further advection of warm southerly air to this area, leading to an amplification of the warming (Bengtsson et al., 2004; Crespin et al., 2009).

Our AN ice-core data show that these positive feedback processes were not restricted to the European Arctic but also affected at least the Kara Sea region to SZ, even though with a special feature. In the AN $\delta^{18} \mathrm{O}$ record, the ETCW 
Table 1. Correlation coefficients (annual and 5yrm values) between $\mathrm{AN} \delta^{18} \mathrm{O}$ and meteorological time series (detrended and original records). Bold (italic) numbers indicate correlation coefficients statistically significant at the level of $p=0.05(p=0.1)$, verified by a one-tailed $t$ test taking into account the reduced degrees of freedom due to autocorrelation (lag 1).

\begin{tabular}{lcrrrr}
\hline & & \multicolumn{2}{c}{ Detrended data } & \multicolumn{2}{c}{ Original data } \\
Time series & Time period & $r_{\text {annual }}$ & $r_{5 y r m}$ & $r_{\text {annual }}$ & $r_{5 y r m}$ \\
\hline Vard $\varnothing$ annual & $1840-1998$ & $\mathbf{0 . 2 0}$ & $\mathbf{0 . 5 5}$ & $\mathbf{0 . 3 8}$ & $\mathbf{0 . 7 6}$ \\
Vardø MAM & $1840-1998$ & 0.11 & 0.20 & $\mathbf{0 . 3 0}$ & $\mathbf{0 . 5 9}$ \\
Vard $\varnothing$ JJA & $1840-1998$ & 0.13 & 0.43 & $\mathbf{0 . 1 6}$ & 0.43 \\
Vardø SON & $1840-1998$ & $\mathbf{0 . 1 5}$ & $\mathbf{0 . 5 1}$ & $\mathbf{0 . 3 0}$ & $\mathbf{0 . 6 9}$ \\
Vardø DJF & $1841-1998$ & $\mathbf{0 . 1 9}$ & $\mathbf{0 . 4 6}$ & $\mathbf{0 . 3 4}$ & $\mathbf{0 . 6 9}$ \\
Arkhangelsk annual & $1814-1998^{\mathrm{a}}$ & $\mathbf{0 . 1 9}$ & $\mathbf{0 . 5 1}$ & $\mathbf{0 . 2 7}$ & $\mathbf{0 . 5 7}$ \\
$T_{\text {NA }}$ annual & $1802-1998^{\mathrm{b}}$ & $\mathbf{0 . 2 0}$ & 0.47 & $\mathbf{0 . 5 4}$ & 0.78 \\
Arctic annual & $1875-1998$ & $\mathbf{0 . 4 3}$ & 0.72 & $\mathbf{0 . 5 5}$ & 0.81 \\
\hline
\end{tabular}

${ }^{a}$ Missing data: $1832-1833$ and corresponding 5 yrm values. ${ }^{b}$ Missing data: $1803-1806$,

1822-1823, 1825, 1828 and corresponding 5 yrm values.

exhibits a double-peak shape with two distinct maxima around 1921/1922 and 1937/1938 (Fig. 5), indicating two major warming pulses. This specific ETCW pattern and particularly the strong warming around 1920 are to our knowledge only detected in very few regional SAT time series (i.e. Svalbard, Vard $\varnothing$ and Arkhangelsk, Fig. 5). Thus, they can be interpreted as a regional SAT feature restricted to the Barents and Kara seas region. The maximum $\mathrm{AN} \delta^{18} \mathrm{O}$ values during the ETCW were not reached again in the 20th century and, moreover, represent the highest of the entire AN ice core record, i.e. about the last three millennia.

\subsection{Long-term scale climate interpretation (900-1998)}

Our long-term $\mathrm{AN} \delta^{18} \mathrm{O}$ record (i.e. $15 \mathrm{yrm}$ values) shows a slightly decreasing trend (about $-0.11 \%$ o per century) from 900 to 1760 , characterized by a marked decadal-scale variability (Fig. 6). This is consistent with a general Late Holocene cooling in the Arctic linked to decreasing summer insolation (Kaufman et al., 2009). However, a part of this AN $\delta^{18} \mathrm{O}$ decrease might also be related to the long-term growth of the AN ice cap as already indicated by the annual-layer thickness data and as previously discussed for smaller Arctic ice caps by Koerner and Fisher (2002). A higher ice-cap elevation should result in lower $\delta^{18} \mathrm{O}$ values (altitude effect).

To our knowledge, there exist no observations of isotope lapse rates for the AN ice cap. $\delta^{18} \mathrm{O}$ gradients of $-0.16 \%$ o per $100 \mathrm{~m}$ and $-0.1 \%$ per $100 \mathrm{~m}$ are reported for the windward slope of the nearby Vavilov ice cap at SZ (Klementyev et al., 1991) and for Lomonosovfonna (Pohjola et al., 2002), respectively. Using these lapse rates to explain the long-term decrease of $\mathrm{AN} \delta^{18} \mathrm{O}$ (about $1 \%$ o between 900 and 1760) by a growing ice cap only would yield unrealistic elevation increases of $590 \mathrm{~m}$ and $950 \mathrm{~m}$, respectively. Both lapse rates are significantly smaller than the $-0.62 \%$ per $100 \mathrm{~m}$ reported for Greenland (Dansgaard et al., 1973), which would be equivalent to a more realistic elevation increase of about
$150 \mathrm{~m}$. Therefore, we consider the long-term trend not to be only growth-related but also to contain a significant climate component. The modified Nye model for the AN ice core (Fritzsche et al., 2010) predicts an elevation increase of only about $72 \mathrm{~m}$ between 900 and 1760 , which would only explain a $\delta^{18} \mathrm{O}$ decrease of $0.07 \%$ o to $0.45 \%$ o calculated with the mentioned gradients. Consequently, we assume the decreasing summer insolation to be the main controlling factor for the long-term decrease in $\mathrm{AN} \delta^{18} \mathrm{O}$, consistent with most other Arctic records.

In 1760 , the $\delta^{18} \mathrm{O}$ values drop rapidly to the lowest values of the entire AN ice-core record: a cold period of about one century with minimum temperatures around 1800 (Fig. 6), right after the eruption of Laki (Iceland) in 1783, which might have caused and/or amplified a distinct regional cooling. Moreover, this period coincides with the Dalton minimum of solar activity. After 1800 , AN $\delta^{18} \mathrm{O}$ data show a significant warming trend culminating in the absolute SAT maximum during the ETCW.

Assuming open water to be the main source of sea salt deposited on the AN ice cap, as first-order approximation seasalt concentrations in the AN ice core would be negatively correlated with the distance to open water if atmospheric circulation strength and pathways were the same (Abram et al., 2013, and references therein). The longer the distance to the open-water source and the higher the ice-cap elevation, the higher is the amount of sea-salt aerosol loss during transport. Following Abram et al. (2013), this "traditional" interpretation might be applicable in areas where open water dominates and sea-salt concentrations peak in summer. The Barents and Kara seas are rather free of sea ice in summer and autumn, the seasons with the highest precipitation on SZ ice caps (Opel et al., 2009). Thus, we use this approach for a long-term interpretation of our AN sodium record, even though the high-resolution sea-salt (i.e. sodium) record in the AN ice core is altered by melt, shows peaks in summer as 


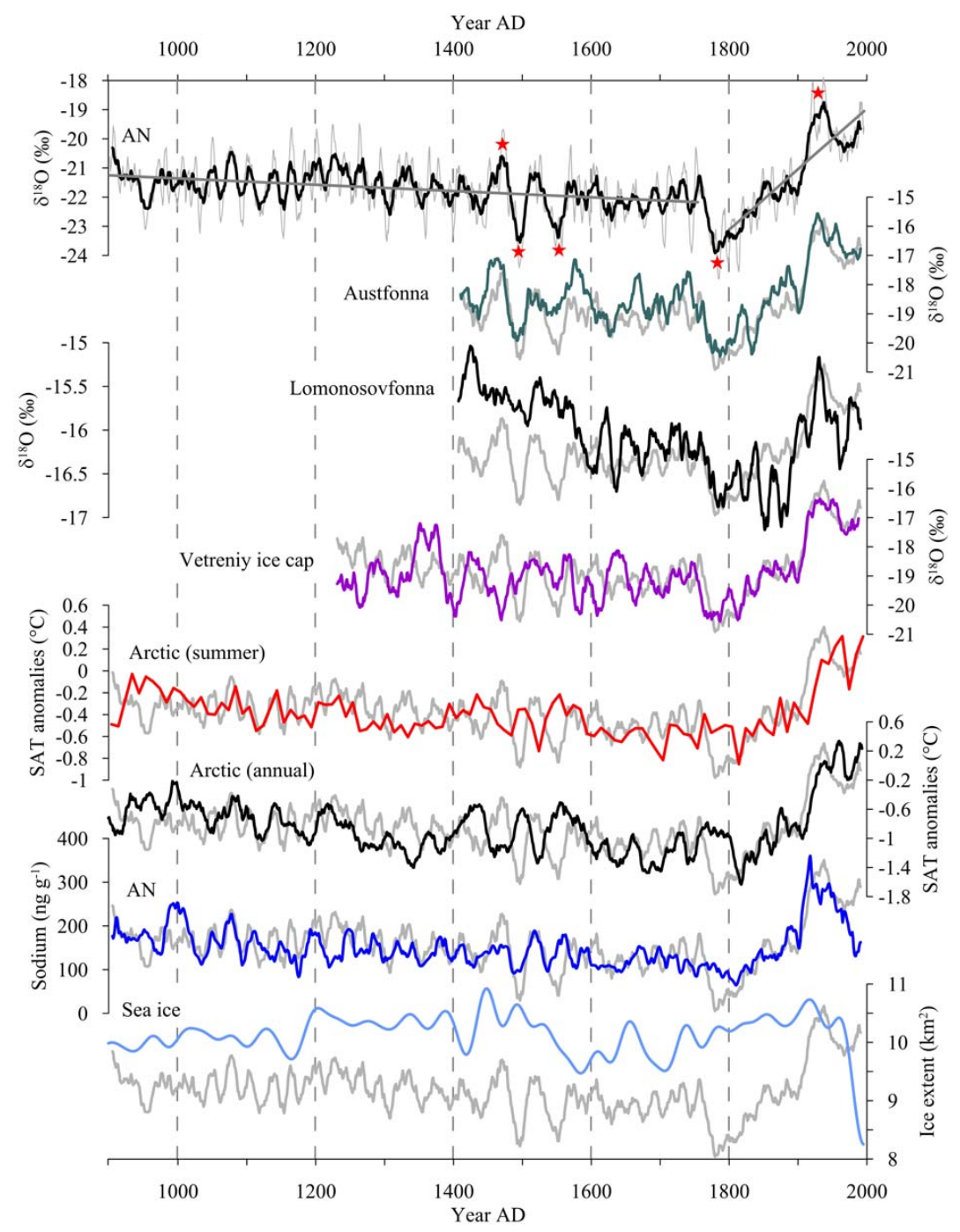

Fig. 6. AN $\delta^{18} \mathrm{O}$ record (including linear trends for 900-1760 and 1800-1998) compared to (from top to bottom) Austfonna and Lomonosovfonna $\delta^{18} \mathrm{O}$ (Isaksson et al., 2005), Vetreniy ice-cap $\delta^{18} \mathrm{O}$ (Henderson, 2002; data from Kinnard et al., 2011), Arctic summer SAT anomalies (Kaufman et al., 2009), Arctic annual SAT anomalies (PAGES 2k Consortium et al., 2013), AN sodium concentrations, and Arctic sea-ice extent (Kinnard et al., 2011) records. Displayed are $5 \mathrm{yrm}$ values for $\mathrm{AN} \delta^{18} \mathrm{O}$ (thin line), $15 \mathrm{yrm}$ values for AN $\delta^{18} \mathrm{O}$, Austfonna and Lomonosovfonna $\delta^{18} \mathrm{O}$, Vetreniy ice-cap $\delta^{18} \mathrm{O}$, Arctic annual SAT anomalies, AN sodium concentrations and Arctic sea ice (thick lines) as well as $10 \mathrm{yr}$ means for Arctic summer SAT (thick line). For easier comparison, to each graph the $\mathrm{AN} \delta^{18} \mathrm{O} 15 \mathrm{yrm}$ record is added in light grey in the same scale as above and adjusted for the best fit of the 20th century maximum (except for Arctic sea ice). Abrupt warming and cooling events exceeding the dominant variability of the $\mathrm{AN} \delta^{18} \mathrm{O}$ record are marked by a red asterisk. Note the different scale for the Lomonosovfonna $\delta^{18} \mathrm{O}$ record.

well as winter layers and represents, therefore, rather a melt signal than a seasonal deposition signal (Weiler et al., 2005).

The AN sodium record exhibits distinct similarities to the AN $\delta^{18} \mathrm{O}$ over most of the past $1100 \mathrm{yr}$ (Fig. 6). The longterm decrease supports the assumption of a growing ice cap (see above). Mostly, warmer (colder) periods exhibit higher (lower) sodium concentrations, indicating the direct regional link between temperature and sea-ice dynamics. Less seaice cover and more open water in warmer times might increase the proportion of regional moisture with higher seasalt concentrations and, therefore, lead to a more efficient transport and deposition of sea salt onto the AN ice cap. Similar transport and deposition mechanisms were described for the Lomonosovfonna ice core (Kekonen et al., 2005). On the contrary, in cold periods with larger sea-ice extent and less regional open water sources, the transport efficiency is reduced due to a longer transport distance and less sea salt is deposited on the AN ice cap. Consequently, the coldest period recorded by $\mathrm{AN} \delta^{18} \mathrm{O}$ around 1800 also yielded the lowest sodium concentrations for the past $1100 \mathrm{yr}$. However, as indicated in Fig. 6 this linkage does not hold over the whole record. Partly, warmer (colder) periods are characterized 
by lower (higher) sodium concentrations. This implies also other processes being involved, e.g. changing patterns of atmospheric circulation dynamics and/or pathways of air-mass advection, whereas ion leaching and run-off seem rather unlikely (Opel et al., 2009). In general, there are only minor similarities between AN sea salt and the Arctic-wide sea-ice reconstruction of Kinnard et al. (2011). This implies that AN sea-salt concentrations are not representative of the whole Arctic but record a rather regional signal for the Barents and Kara seas region.

In the early 20th century, about one decade before the first $\delta^{18} \mathrm{O}$ maximum around $1921 / 1922$, an unprecedented rise in sodium concentration can be observed (Fig. 6). Even though this sodium peak might be amplified by meltwater infiltration (Opel et al., 2009) it distinctly precedes the warming and indicates major shifts in the regional sea-ice dynamics and/or air-mass advection prior to the ETCW. Correspondingly, the August sea-ice extent of the Kara Sea shows a strong interannual variability from 1911 to 1915 (Polyakov et al., 2003a), which might be related to this sea-salt ion peak, whereas positive sea-ice extent anomalies are reported for the eastern Nordic Seas (Vinje, 2001) as well as for the Barents Sea (Vinje, 1999). Similar to the Svalbard records of Austfonna (Watanabe et al., 2001) and Lomonosovfonna (Kekonen et al., 2005) the AN sodium concentrations remain on a high level until the middle of the 20th century before they decrease sharply, although again-increasing $\mathrm{AN} \delta^{18} \mathrm{O}$ values indicate a climate warming and a strongly decreasing sea-ice extent is reported for the Arctic (Kinnard et al., 2011).

Our AN $\delta^{18} \mathrm{O}$ record exhibits a similar overall pattern (centennial-scale trend) as the $\delta^{18} \mathrm{O}$ records of Austfonna (Svalbard) (Isaksson et al., 2005) and the Vetreniy ice cap (FJL) (Henderson, 2002). Moreover, the spatial significance of the $\mathrm{AN} \delta^{18} \mathrm{O}$ record as SAT proxy for the western Eurasian Arctic is also underlined by a marked multidecadal accordance with the Austfonna record for the last six centuries and with the Vetreniy ice cap record for the last three centuries (Fig. 6). The detrended AN and Austfonna $\delta^{18} \mathrm{O}$ records are strongly correlated over the time pe$\operatorname{riod} 1400-1998\left(r_{\text {annual }}=0.37, p=0.01 ; r_{5 y r m}=0.63, p=\right.$ $\left.0.01 ; r_{15 \mathrm{yrm}}=0.85, p=0.1\right)$. The corresponding correlation coefficients for AN and Vetreniy ice cap $\delta^{18} \mathrm{O}$ data over the time period $1225-1995$ are distinctly lower $\left(r_{\text {annual }}=0.23\right.$, $\left.p=0.01 ; r_{5 \mathrm{yrm}}=0.42, p=0.01 ; r_{15 \mathrm{yrm}}=0.61, p=0.1\right)$ due to the decreasing similarity before 1800 , which is almost completely lost before 1700 . Consequently, for the period 1750-1995 (detrended records), Vetreniy ice cap $\delta^{18} \mathrm{O}$ data are more strongly correlated to those of AN $\left(r_{\text {annual }}=0.30\right.$, $\left.p=0.01 ; r_{5 \mathrm{yrm}}=0.53, p=0.05\right)$ than Austfonna $\delta^{18} \mathrm{O}$ data $\left(r_{\text {annual }}=0.23, p=0.01 ; r_{5 y r m}=0.48, p=0.05\right)$.

The ice cores from Austfonna and the Vetreniy ice cap were taken at relative low elevations (750 and $500 \mathrm{~m}$ a.s.l., respectively) and are, thus, comparable to the AN ice core (Fig. 6). However, both records are about 3\%o less depleted in $\delta^{18} \mathrm{O}$ due to their more maritime locations in the western
Eurasian Arctic with milder climate conditions compared to SZ. Some of the slight deviations between AN and Austfonna $\delta^{18} \mathrm{O}$ records might be caused by the lower sampling resolution (about $25 \mathrm{~cm}$ ) of the Austfonna ice core and its dating by a Nye model not taking into account the probable growth of the ice cap analogously to the AN ice cap. As FJL is situated between Svalbard and SZ the ice core from the Vetreniy ice cap should reflect the same multidecadal SAT variability also before 1700 . We assume that below the Laki reference horizon (1783) the Vetreniy ice-core age model progressively overestimates the age by up to about $100 \mathrm{yr}$ in the oldest part of the record. A possible offset between different dating approaches for this core has already been noticed by Henderson (2002).

The $\delta^{18} \mathrm{O}$ record from the high-elevation Lomonosovfonna ( $1250 \mathrm{~m}$ a.s.l.), the best-studied Svalbard ice core (e.g. Isaksson et al., 2005), exhibits, conversely, only a minor long-term accordance with our AN record. However, after detrending (1400-1998), the record shows some correlation to our $\mathrm{AN} \delta^{18} \mathrm{O}$ data $\left(r_{\text {annual }}=0.25, p=0.01 ; r_{5 \mathrm{yrm}}=0.44\right.$, $\left.p=0.01 ; r_{15 \mathrm{yrm}}=0.68, p=0.11\right)$, even though significantly weaker as compared to Austfonna. Due to its higher elevation and a shorter distance to the Atlantic Ocean in comparison to the three other ice-core locations, Lomonosovfonna receives most probably different atmospheric signals. This is supported by a $\delta^{18} \mathrm{O}$ range that is only about half of that of the AN, Austfonna and Vetreniy ice cores (Fig. 6).

In summary, with the presented new AN $\delta^{18} \mathrm{O}$ record we are able to expand the SAT information for the Barents and Kara seas region back to 900 . Our $\mathrm{AN} \delta^{18} \mathrm{O}$ record displays the same overall pattern as the Arctic-wide reconstructions of Kaufman et al. (2009) and PAGES 2k Consortium (2013), resulting in a medium correlation to the latter $\left(r_{\text {annual }}=0.23\right.$, $\left.p=0.01 ; r_{5 \mathrm{yrm}}=0.38, p=0.01 ; r_{15 \mathrm{yrm}}=0.52, p=0.1\right)$ for detrended data (900-1998). However, there are also several distinct differences, in particular regarding the timing and peculiarities of several specific events. For instance, the SAT minimum around 1800 as well as the following warming (ETCW) occurred distinctly earlier by a couple of decades and more pronounced in the AN as well as Austfonna and Vetreniy ice cap $\delta^{18} \mathrm{O}$ records than in the Arctic-wide scale (Fig. 6). There are mainly two possible explanations for these differences: spatial and/or seasonal effects.

The reconstructions of Kaufman et al. (2009) and PAGES 2k Consortium (2013) are predominantly based on records from the North American Arctic and Greenland (see above). It is therefore likely that they are spatially biased and their significance is lower for the Eurasian Arctic. This points again to a particular climate regime of the Barents and Kara seas region framed by the AN and Austfonna ice-core sites and indicates that the Eurasian and the North American Arctic have experienced distinctly different SAT patterns over the past centuries. A possible lead of the western Eurasian Arctic SAT record might indicate that such major SAT changes could have originated in the Barents and Kara 
seas region and then progressively expanded to the rest of the Arctic, reaching the North American Arctic only a few years later. However, this cannot be verified by meteorological data because there do not exist corresponding time series in the North American Arctic.

On the other hand, the reconstruction of Kaufman et al. (2009) mainly represents summer SAT and the AN $\delta^{18} \mathrm{O}$ record instead rather annual SAT. Hence, seasonal effects might also contribute to the observed differences. This assumption is supported by a recent study of Sidorova et al. (2013), also showing a lead of $\mathrm{AN} \delta^{18} \mathrm{O}$ over tree-ring proxies from the nearby Taimyr Peninsula as well as northern Yakutia for the 1800 SAT minimum and the subsequent warming to the ETCW. Moreover, in particular the first part of the ETCW occurred predominantly in winter (Polyakov et al., 2003b) and was consequently recorded in our annual $\mathrm{AN} \delta^{18} \mathrm{O}$ record but not in the summer SAT proxies used by Kaufman et al. (2009) and Sidorova et al. (2013). However, the reconstruction of annual Arctic SAT (PAGES 2k Consortium, 2013) is quite similar to the summer SAT record of Kaufman et al. (2009) over the past millennium and shows only slight deviations. This indicates that spatial effects (i.e. geographic location of used proxies) might be of more relevance to explain the observed different timings of specific SAT patterns than seasonal effects (i.e. the time period covered by a proxy).

Although our $\mathrm{AN} \delta^{18} \mathrm{O}$ data indicate higher temperatures around 900 and in the 13th century than in the 17th century, no distinct long-lasting climate epochs such as the Medieval Climate Anomaly or the Little Ice Age (LIA) are readily detectable in the AN $\delta^{18} \mathrm{O}$ record (Fig. 6). Only the cold period around 1800 and the subsequent warming could be interpreted as the final stage and termination of the LIA. As the same is true for the Austfonna $\delta^{18} \mathrm{O}$ record, we conclude that the Barents and Kara seas region did not experience a pronounced LIA. In contrast, the AN $\delta^{18} \mathrm{O}$ record exhibits several abrupt cooling and warming events, such as in the 15th and 16th as well as in the 18th and 20th centuries (Fig. 6). These events are of at least regional significance, as they are also detectable in the Austfonna and partly in the Vetreniy ice cap $\delta^{18} \mathrm{O}$ records and are concerning range and change rates comparable to the SAT rise before 1920 leading to the ETCW. They exceed the dominant variability of our time series, which is measured by two standard deviations of the high-pass ( $400 \mathrm{yr}$ FIR) filtered $\delta^{18} \mathrm{O}$ record. To be consistent with Fig. 6, and as we don't interpret single years, we applied the high-pass filter to the $15 \mathrm{yrm}$ data, but the results are not sensitive to the details of this process.

These abrupt changes and resulting cool and warm periods might also be triggered by internal climate variability as assumed for the ETCW, i.e. related to changes in the prevailing wind patterns and air-mass transport caused by shifts between dominant atmospheric circulation types (stronger meridional or zonal components) as well as to corresponding sea-ice feedbacks in the Barents and Kara seas region.
This interpretation is supported by respective changes in the AN sodium record in the 15th and 16th centuries (Fig. 6) as well as by model results for the late 15th century (Crespin et al., 2009). However, the existing regional sea-ice records are either too short, as in the case of the Barents Sea (Vinje, 1999), or show only slight variations but no similar patterns for the 15th and 16th centuries (Fig. 6), probably because of the Arctic scale (Kinnard et al., 2011).

The period with abrupt changes in the AN and Austfonna $\delta^{18} \mathrm{O}$ records (i.e. the 15 th to 20 th centuries, Fig. 6) fits well to reconstructions of significantly increased strengths of the Icelandic Low and the Siberian High from 1400 to 2000 compared to the preceding centuries (Meeker and Mayewski, 2002). Both atmospheric pressure centres play a major role for the atmospheric circulation in the high northern latitudes from the North Atlantic to Asia. The joint increased strength of the Icelandic Low and the Siberian High is assumed to cause higher atmospheric circulation variability over the Northern Atlantic and in the Eurasian Arctic. This could, therefore, lead to rapidly changing air-mass advection patterns (such as more meridional or zonal air-mass transport) and associated sea-ice feedbacks and might be a precondition for the occurrence of such abrupt SAT changes in the western Eurasian Arctic.

Whereas our AN $\delta^{18} \mathrm{O}$ and the Arctic-wide SAT records (Kaufman et al., 2009; PAGES 2k Consortium, 2013) display similar patterns in the 11th and 12th centuries, they show clearly contrary trends in the 15th and 16th centuries (Fig. 6). Abrupt cooling events in the Barents and Kara seas region are accompanied by warming events on the Arctic scale and vice versa. The causes of these differences may be similar to those already discussed for the periods around 1800 and in the early 20th century. This pattern might be interpreted as a kind of SAT see-saw on a predominantly spatial scale (Eurasian vs. North American Arctic) but may contain also, to a lesser extent, seasonal effects (annual vs. summer).

\section{Conclusions}

The results presented in this paper highlight the potential of the AN ice core as a high-resolution climate archive for the Late Holocene, i.e. about the last three millennia. Beside a long-term decrease due to climate cooling and ice-cap growth the AN $\delta^{18} \mathrm{O}$ record shows evidence of major temperature changes over the last millennium that are representative at least of the western Eurasian Arctic, i.e. the Barents and Kara seas region. Of particular importance are several abrupt cooling and warming events leading e.g. to the absolute SAT minimum around 1800 and the absolute SAT maximum in the early 20th century, accompanied by significant changes in sodium concentrations. The ETCW exhibits a specific double-peaked shape typical of the Barents and Kara seas region. Abrupt changes in the last centuries might be caused by internal climate dynamics related to shifts of 
atmospheric circulation patterns and corresponding sea-ice feedbacks.

Acknowledgements. We thank Rainer Schütt, Urs Ruth, Birthe Twarloh, Anika Schmidt, Ute Bastian, Christin Orfert, Lutz Schönicke and Cindy Springer for their sampling and analytical effort in the AWI laboratories as well as Hubertus Fischer, Dietmar Wagenbach and Thomas Laepple for valuable discussions on data and earlier manuscript versions. Furthermore, we thank Nerilie Abram and an anonymous reviewer for their helpful comments and constructive criticism. This study contributes to the Eurasian Arctic Ice $4 k$ project (grant OP 217/2-1 awarded to Thomas Opel by Deutsche Forschungsgemeinschaft). The drilling project was funded by the German Ministry of Education and Research (grant 03PL027A/3).

Edited by: N. Abram

\section{References}

Abram, N. J., Wolff, E. W., and Curran, M. A. J.: A review of sea ice proxy information from polar ice cores, Quaternary Sci. Rev., 79, 168-183, doi:10.1016/j.quascirev.2013.01.011, 2013.

AMAP: Snow, Water, Ice and Permafrost in the Arctic (SWIPA): Climate Change and the Cryosphere, Oslo, Norway, xii + 538 pp., 2011.

Bengtsson, L., Semenov, V. A., and Johannessen, O. M.: The early twentieth-century warming in the Arctic - A possible mechanism, J. Climate, 17, 4045-4057, doi:10.1175/15200442(2004)017<4045:TETWIT>2.0.CO;2, 2004.

Brohan, P., Kennedy, J. J., Harris, I., Tett, S. F. B., and Jones, P. D.: Uncertainty estimates in regional and global observed temperature changes: A new data set from 1850, J. Geophys. Res.Atmos., 111, D12106, doi:10.1029/2005jd006548, 2006.

Crespin, E., Goosse, H., Fichefet, T., and Mann, M. E.: The 15th century Arctic warming in coupled model simulations with data assimilation, Clim. Past, 5, 389-401, doi:10.5194/cp-5-3892009, 2009.

Dansgaard, W., Johnsen, S., Clausen, H., and Gundestrup, N.: Stable isotope glaciology, Meddelelser om Grønland, 197, 1-53, 1973.

Divine, D., Isaksson, E., Martma, T., Meijer, H. A. J., Moore, J., Pohjola, V., van de Wal, R. S. W., and Godtliebsen, F.: Thousand years of winter surface air temperature variations in Svalbard and northern Norway reconstructed from ice-core data, Polar Res., 30, 7379, doi:10.3402/polar.v30i0.7379, 2011.

Fritzsche, D., Wilhelms, F., Savatyugin, L. M., Pinglot, J. F., Meyer, H., Hubberten, H. W., and Miller, H.: A new deep ice core from Akademii Nauk ice cap, Severnaya Zemlya, Eurasian Arctic: first results, Ann. Glaciol., 35, 25-28, doi:10.3189/172756402781816645, 2002.

Fritzsche, D., Schütt, R., Meyer, H., Miller, H., Wilhelms, F., Opel, T., and Savatyugin, L. M.: A 275 year ice-core record from Akademii Nauk ice cap, Severnaya Zemlya, Russian Arctic, Ann. Glaciol., 42, 361-366, doi:10.3189/172756405781812862, 2005.
Fritzsche, D., Opel, T., and Meyer, H.: Ice core from Akademii Nauk ice cap, Severnaya Zemlya (Russian Arctic), dated with a Nye model modified for a growing glacier, Geophys. Res. Abstr., EGU2010-10210, EGU General Assembly 2010, Vienna, Austria, 2010.

Grant, A. N., Brönnimann, S., Ewen, T., Griesser, T., and Stickler, A.: The early twentieth century warm period in the European Arctic, Meteorol. Z., 18, 425-432, doi:10.1127/09412948/2009/0391, 2009.

Henderson, K.: An ice core paleoclimate study of Windy Dome, Franz Josef Land (Russia): Development of a recent climate history for the Barents Sea, $\mathrm{PhD}$ thesis, The Ohio State University, 218 pp., 2002.

Isaksson, E., Divine, D., Kohler, J., Martma, T., Pohjola, V., Motoyama, H., and Watanabe, O.: Climate oscillations as recorded in Svalbard ice core delta O-18 records between AD 1200 and 1997, Geogr. Ann. A, 87, 203-214, doi:10.1111/j.04353676.2005.00253.x, 2005.

Kaufman, D. S., Schneider, D. P., McKay, N. P., Ammann, C. M., Bradley, R. S., Briffa, K. R., Miller, G. H., Otto-Bliesner, B. L., Overpeck, J. T., Vinther, B. M., and Arctic Lakes 2k Project Members: Recent Warming Reverses Long-Term Arctic Cooling, Science, 325, 1236-1239, doi:10.1126/science.1173983, 2009.

Kekonen, T., Moore, J., Peramaki, P., Mulvaney, R., Isaksson, E., Pohjola, V., and van de Wal, R. S. W.: The 800 year long ion record from the Lomonosovfonna (Svalbard) ice core, J. Geophys. Res.-Atmos., 110, D07304, doi:10.1029/2004jd005223, 2005.

Kinnard, C., Zdanowicz, C. M., Fisher, D. A., Isaksson, E., de Vernal, A., and Thompson, L. G.: Reconstructed changes in Arctic sea ice over the past 1,450 years, Nature, 479, 509-512, doi:10.1038/nature10581, 2011.

Klementyev, O. L., Potapenko, V. Y., Savatyugin, L. M., and Nikolaev, V. I.: Studies of the internal structure and thermalhydrodynamic state of the Vavilov Glacier, Archipelago Severnaya Zemlya, in: Glaciers-Ocean-Atmosphere Interactions. Proceedings of the International Symposium held at St. Petersburg, September 1990, edited by: Kotlyakov, V. M., Ushakov, A., and Glazovsky, A., IAHS Publication, IAHS Press, Wallingford, 4959, 1991.

Koerner, R. M.: Some comments on climatic reconstructions from ice cores drilled in areas of high melt, J. Glaciol., 43, 90-97, 1997.

Koerner, R. M. and Fisher, D. A.: Ice-core evidence for widespread Arctic glacier retreat in the Last Interglacial and the early Holocene, Ann. Glaciol., 35, 19-24, doi:10.3189/172756402781817338, 2002.

Kotlyakov, V. M., Zagorodnov, V. S., and Nikolaev, V. I.: Drilling on ice caps in the Soviet Arctic and on Svalbard and prospects of ice core treatment, in: Arctic Research. Advances and prospects. Proceedings of the Conference of Arctic and Nordic Countries on Coordination of Research in the Arctic, Leningrad, December 1988, edited by: Kotlyakov, V. M. and Sokolov, V. E., Nauka, Moscow, 5-18, 1990.

Kotlyakov, V. M., Arkhipov, S. M., Henderson, K. A., and Nagornov, O. V.: Deep drilling of glaciers in Eurasian Arctic as a source of paleoclimatic records, Quaternary Sci. Rev., 23, 13711390, doi:10.1016/j.quascirev.2003.12.013, 2004. 
Meeker, L. D. and Mayewski, P. A.: A 1400-year high-resolution record of atmospheric circulation over the North Atlantic and Asia, Holocene, 12, 257-266, doi:10.1191/0959683602hl542ft, 2002.

Meyer, H., Schönicke, L., Wand, U., Hubberten, H. W., and Friedrichsen, H.: Isotope studies of hydrogen and oxygen in ground ice - Experiences with the equilibration technique, Isot. Environ. Healt. S., 36, 133-149, doi:10.1080/10256010008032939, 2000.

Moore, J. C., Beaudon, E., Kang, S. C., Divine, D., Isaksson, E., Pohjola, V. A., and van de Wal, R. S. W.: Statistical extraction of volcanic sulphate from nonpolar ice cores, J. Geophys. Res.Atmos., 117, D03306, doi:10.1029/2011jd016592, 2012.

Nye, J. F.: Correction factor for accumulation measured by the ice thickness of the annual layers in an ice sheet, J. Glaciol., 4, 785788, 1963.

Opel, T., Fritzsche, D., Meyer, H., Schütt, R., Weiler, K., Ruth, U., Wilhelms, F., and Fischer, H.: 115 year ice-core data from Akademii Nauk ice cap, Severnaya Zemlya: high-resolution record of Eurasian Arctic climate change, J. Glaciol., 55, 21-31, doi:10.3189/002214309788609029, 2009.

Overpeck, J., Hughen, K., Hardy, D., Bradley, R., Case, R., Douglas, M., Finney, B., Gajewski, K., Jacoby, G., Jennings, A., Lamoureux, S., Lasca, A., MacDonald, G., Moore, J., Retelle, M., Smith, S., Wolfe, A., and Zielinski, G.: Arctic environmental change of the last four centuries, Science, 278, 1251-1256, doi:10.1126/science.278.5341.1251, 1997.

PAGES 2k Consortium: Continental-scale temperature variability during the past two millennia, Nat. Geosci., 6, 339-346, doi:10.1038/ngeo1797, 2013.

Pinglot, J. F., Vaikmae, R. A., Kamiyama, K., Igarashi, M., Fritzsche, D., Wilhelms, F., Koerner, R., Henderson, L., Isaksson, E., Winther, J. G., Van de Wal, R. S. W., Fournier, M., Bouisset, P., and Meijer, H. A. J.: Ice cores from Arctic subpolar glaciers: chronology and post-depositional processes deduced from radioactivity measurements, J. Glaciol., 49, 149-158, doi:10.3189/172756503781830944, 2003.

Pohjola, V. A., Moore, J. C., Isaksson, E., Jauhiainen, T., van de Wal, R. S. W., Martma, T., Meijer, H. A. J., and Vaikmae, R.: Effect of periodic melting on geochemical and isotopic signals in an ice core from Lomonosovfonna, Svalbard, J. Geophys. Res.Atmos., 107, ACL 1.1-ACL 1.14, doi:10.1029/2000jd000149, 2002.

Polyakov, I. V., Alekseev, G. V., Bekryaev, R. V., Bhatt, U. S., Colony, R., Johnson, M. A., Karklin, V. P., Walsh, D., and Yulin, A. V.: Long-term ice variability in Arctic marginal seas, J. Climate, 16, 2078-2085, doi:10.1175/15200442(2003)016<2078:LIVIAM>2.0.CO;2, 2003a.

Polyakov, I. V., Bekryaev, R. V., Alekseev, G. V., Bhatt, U. S., Colony, R. L., Johnson, M. A., Maskshtas, A. P., and Walsh, D.: Variability and trends of air temperature and pressure in the maritime Arctic, 1875-2000, J. Climate, 16, 2067-2077, doi:10.1175/1520-0442(2003)016<2067:VATOAT>2.0.CO;2, 2003 b.
Sidorova, O. V., Saurer, M., Andreev, A., Fritzsche, D., Opel, T., Naurzbaev, M. M., and Siegwolf, R.: Is the 20th century warming unprecedented in the Siberian north?, Quaternary Sci. Rev., 73, 93-102, doi:10.1016/j.quascirev.2013.05.015, 2013.

Spielhagen, R. F., Werner, K., Sørensen, S. A., Zamelczyk, K., Kandiano, E., Budeus, G., Husum, K., Marchitto, T. M., and Hald, M.: Enhanced Modern Heat Transfer to the Arctic by Warm Atlantic Water, Science, 331, 450-453, doi:10.1126/science.1197397, 2011.

Vinje, T.: Barents Sea ice edge variation over the past 400 years, in: WMO/TD, Workshop on Sea-Ice Charts of the Arctic, Seattle, WA, 4-6, 1999.

Vinje, T.: Anomalies and trends of sea-ice extent and atmospheric circulation in the Nordic Seas during the period 1864-1998, J. Climate, 14, 255-267, 2001.

Wanner, H., Beer, J., Bütikofer, J., Crowley, T. J., Cubasch, U., Flückiger, J., Goosse, H., Grosjean, M., Joos, F., Kaplan, J. O., Küttel, M., Müller, S. A., Prentice, I. C., Solomina, O., Stocker, T. F., Tarasov, P., Wagner, M., and Widmann, M.: Mid- to Late Holocene climate change: an overview, Quaternary Sci. Rev., 27, 1791-1828, doi:10.1016/j.quascirev.2008.06.013, 2008.

Watanabe, O., Motoyama, H., Igarashi, M., Kamiyama, K., Matoba, S., Goto-Azuma, K., Narita, H., and Kameda, T.: Studies on climatic and environmental changes during the last few hundred years using ice cores from various sites in Nordaustlandet, Svalbard, Memoirs of National Institute of Polar Research, Special Issue 54, 227-242, 2001.

Weiler, K., Fischer, H., Fritzsche, D., Ruth, U., Wilhelms, F., and Miller, H.: Glaciochemical reconnissance of a new ice core from Severnya Zemlya, Eurasian Arctic, J. Glaciol., 51, 64-74, doi:10.3189/172756505781829629, 2005.

Wilhelms, F.: Messung dielektrischer Eigenschaften polarer Eiskerne (Measuring the Dielectric Properties of Polar Ice Cores), Berichte zur Polarforschung (Reports on Polar Research), Alfred Wegener Institute for Polar and Marine Research, Bremerhaven, 171 pp., 2000.

Wood, K. R. and Overland, J. E.: Early 20th century Arctic warming in retrospect, Int. J. Climatology, 30, 1269-1279, doi:10.1002/joc.1973, 2010.

Wood, K. R., Overland, J. E., Jónsson, T., and Smoliak, B. V.: Air temperature variations on the Atlantic-Arctic boundary since 1802, Geophys. Res. Lett., 37, L17708, doi:10.1029/2010g1044176, 2010.

Zielinski, G. A., Mayewski, P. A., Meeker, L. D., Whitlow, S., Twickler, M. S., Morrison, M., Meese, D. A., Gow, A. J., and Alley, R. B.: Record of Volcanism Since 7000 B.C. from the GISP2 Greenland Ice Core and Implications for the Volcano-Climate System, Science, 264, 948-952, doi:10.1126/science.264.5161.948, 1994. 